\section{Potassium Application Reduces Calcium and Magnesium Levels in Bermudagrass Leaf Tissue and Soil}

\author{
Grady L. Miller \\ Department of Environmental Horticulture, University of Florida, Gainesville, \\ FL 32611-0670
}

Additional index words. turfgrass nutrition, tissue analysis, soil analysis, critical potassium level

\begin{abstract}
High rates of potassium (K) are often applied in an attempt to increase stress tolerance of hybrid bermudagrass [Cynodon dactylon (L.) Pers. $x$ C. transvaalensis Burtt Davy] turfs. Two field-grown bermudagrass cultivars, 'Tifdwarf' and 'Tifway', were used to determine the influence of applied $K$ on plant nutrient content and nutrient retention in two soils. Six rates of $\mathrm{K}$ ranging from 0 to $390 \mathrm{~kg} \cdot \mathrm{ha}^{-1}$ were applied twice per month each growing season from 1992 to 1994. The cultivars were established on both a sand-peat (9:1 by volume) and loamy sand. Potassium chloride and $\mathrm{K}_{2} \mathrm{SO}_{4}$ were compared as sources of $\mathrm{K}$, and were applied simultaneously with $\mathrm{N}$ applications. Extractable soil $\mathrm{K}$ and leaf tissue $K$ concentrations increased with increasing $K$ rates. There was a critical $K$ fertilization level ( 74 to $84 \mathrm{~kg} \cdot \mathrm{ha}^{-1}$ ) for each cultivar and medium combination beyond which no increase in tissue concentration was observed. Increasing $\mathrm{K}$ fertilization resulted in a decrease in extractable $\mathrm{Ca}$ and $\mathrm{Mg}$ in both media with corresponding decreases in tissue $\mathrm{Ca}$ and $\mathrm{Mg}$ concentrations. High $\mathrm{K}$ rates appear to increase the potential for $\mathrm{Ca}$ and $\mathrm{Mg}$ deficiencies in bermudagrass, indicating that rates higher than those that provide sufficient $\mathrm{K}$ levels for normal growth should not be used.
\end{abstract}

Potassium is a primary, essential nutrient for turfgrass production. Application of $\mathrm{K}$ fertilizer as a cultural practice has been suggested as a means of increasing bermudagrass winter hardiness and drought tolerance (Horn, 1969; Miller and Dickens, 1995; Schmidt and Breuninger, 1981). Claims that application of high rates of $\mathrm{K}$ fertilizer alone can enhance stress tolerance are common in the turfgrass industry.

No standard critical values or adequate concentration ranges for tissue $\mathrm{Ca}$ or $\mathrm{Mg}$ in bermudagrass have been established (Cripps et al., 1989), but tissue $\mathrm{Mg}$ concentration is inversely related to tissue $\mathrm{K}$ concentration (Belesky and Wilkinson, 1983; Landua et al., 1973; Matocha and Smith, 1980). Neither Landua etal.(1973) nor Belesky and Wilkinson (1983) reported depression of tissue $\mathrm{Mg}$ concentration below $\approx 1.0 \mathrm{~g} \cdot \mathrm{kg}^{-1}$ dry weight following application of K. Matocha and Smith (1980) and West and Reynolds (1984) reported that $\mathrm{Ca}$ concentrations in bermudagrass and tall fescue (Festuca arundinacea Schreb.) tissue were not reduced by $\mathrm{K}$ fertilization, whereas Cripps et al. (1989), Razmjoo and Kaneko (1993), and Sartain (1993) reported decreases in turfgrass $\mathrm{Ca}$ and $\mathrm{Mg}$ content

Received for publication 28 Mar. 1998. Accepted for publication 13 July 1998. Journal Paper no. R06224, Univ. of Florida Agricultural Experiment Station. The cost of publishing this paper was defrayed in part by the payment of page charges. Under postal regulations, this paper therefore must be hereby marked advertisement solely to indicate this fact.

HortScience, Vol. 34(2), April 1999 native soil, on tissue nutrient concentrations of two bermudagrass cultivars, and on subsequent extractable soil concentrations of $\mathrm{K}, \mathrm{Ca}$, and $\mathrm{Mg}$.

\section{Materials and Methods}

A 3-year study was initiated at the Auburn Univ. Turfgrass Research Center, Auburn, Ala. Two experiments using 'Tifdwarf' and 'Tifway' bermudagrasses were established in Spring 1992 on an Uchee loamy sand (loamy, siliceous, thermic Arenic Hapludult) and a sand-peat ( $9: 1$ by volume) root zone. A complete factorial combination of treatments using $\mathrm{KCl}$ and $\mathrm{K}_{2} \mathrm{SO}_{4}$, both at six rates, was applied to $4.2-\mathrm{m}^{2}$ field plots. Potassium was applied at $0,12,24,49,98$, and $195 \mathrm{~kg} \cdot \mathrm{ha}^{-1}$ per month on the loamy sand soil and $0,24,49,98$, 195 , and $390 \mathrm{~kg} \cdot \mathrm{ha}^{-1}$ per month on the sandpeat. The study was analyzed as a split-plot in space using nested variation as an error term to measure differences between cultivars (McIntosh, 1983). Urea was applied at a rate of 49 $\mathrm{kg} \cdot \mathrm{ha}^{-1} \mathrm{~N}$ on the loamy sand and $98 \mathrm{~kg} \cdot \mathrm{ha}^{-1}$ on the sand-peat. Potassium and $\mathrm{N}$ were applied simultaneously from April through October of each year and watered in with $1.8 \mathrm{~L} \cdot \mathrm{m}^{-2}$. Because $\mathrm{N}$ and $\mathrm{K}$ rates differed, data for each medium were analyzed separately. Initial Mehlich-1 extractable K concentrations were 36 and $15 \mathrm{~kg} \cdot \mathrm{ha}^{-1}$ for the loamy sand and sandpeat, respectively. Based on Auburn Univ. Soil Testing Laboratory recommendations, K concentrations were "low" for the loamy sand and "very low" for the sand-peat. Micronutrients were supplied to the sand-peat during grass establishment. Phosphorus was applied to the sand-peat at $49 \mathrm{~kg} \cdot \mathrm{ha}^{-1}$ in April each year according to Auburn Univ. Soil Testing Laboratory recommendations. Neither loamy sand or sand-peat required amendment to maintain a soil $\mathrm{pH}$ of $6.0 \pm 0.2$.

During the summer months, irrigation was applied as needed to maintain high-quality turf. Weed control was achieved with yearly application of $0.56 \mathrm{~kg} \cdot \mathrm{ha}^{-1}$ dithiopyr [3,5-pyridinedicarbothioic acid, 2-(difluoromethyl)4-(2-methylpropyl-6-(trifluoromethyl)-S,Sdimethyl ester] in mid-March, an application of $2.24 \mathrm{~kg} \cdot \mathrm{ha}^{-1}$ MSMA (monosodium acid methanearsonate) in Aug. 1992, and 0.56 $\mathrm{kg} \cdot \mathrm{ha}^{-1}$ bromoxynil (3,5-dibromo-4hydroxybenzonitrile) in mid-Mar. 1994. 'Tifdwarf' was clipped four to five times per week at a 5-mm cutting height to represent typical golf green conditions. 'Tifway' was mowed four to five times per week at a $12-\mathrm{mm}$ cutting height as would be commonly done for a golf course fairways and tees, and sports turfs. Clippings were removed with each mowing.

Clippings were harvested in May, June, Aug., and Oct. 1993 and May and June 1994 for yield determination. Clippings of a 2-d growth over a $4.2-\mathrm{m}^{2}$ area were collected in a mower catch basket and dried at $70{ }^{\circ} \mathrm{C}$. Leaf tissue and soil samples were taken from each plot for elemental analysis between the first and fifth of each sampling month (MayOctober). Tissue samples were collected from search was to quantify the influence of $\mathrm{K}$,
applied to both a high sand-based soil and a mantaining plant $\mathrm{K}$ concentrations $>17$ $\mathrm{g} \cdot \mathrm{kg}^{-1}$ required rates of 370 and $897 \mathrm{~kg} \cdot \mathrm{ha}^{-1}$ of

Previous studies have not related sufficiency levels of $\mathrm{K}$ to tissue and soil extractable $\mathrm{Ca}$ and $\mathrm{Mg}$ levels. The objective of our re-

ion $\mathrm{K}$ is absorbed and accumulated by plants much more rapidly and to a much greater (Hannaway et al., 1980). Calcium deficiency ceptibility to diseases (Moore et al., 1961), whereas Mg deficiency reduced leaf length, fields and golf courses in the humid and warm High regions of the world (Beard, 197 greens and athletic fields favors K loss through leaching during the long growing season in the of utilization of applied $\mathrm{K}$ is thought mudagrass remains primarily in aboveground removed when the turf is mowed and clippings are removed. Thus, high $\mathrm{K}$ rates, or frequent $\mathrm{K}$ adequate $\mathrm{K}$ in turfgrasses grown on sandy Martin and Matocha, 1973). Rates of applica$K$ required to maintain these $K$ trations depend on soil type, fertility status, and $\mathrm{N}$ rate. Adams et al. (1967) reported that 
a mower catch basket after clipping each plot. The catch basket was carefully cleaned after harvesting each plot to prevent contamination. Tissue samples were prepared by dry ashing at $450{ }^{\circ} \mathrm{C}$ for $4 \mathrm{~h}$, digesting with $10 \mathrm{~mL}$ of $1 \mathrm{~N}$ $\mathrm{HNO}_{3}$ and $10 \mathrm{~mL}$ of $1 \mathrm{~N} \mathrm{HCl}$, and bringing the volume to $100 \mathrm{~mL}$ with water (Hue and Evans, 1986). Soil samples were taken from 0- to 15$\mathrm{cm}$ depth and prepared according to procedures used by Auburn Univ. Soil Testing Laboratory (Hue and Evans, 1986) for Mehlich-1 extractable elemental analysis. Soil and plant extracts were analyzed using an inductively coupled argon plasma spectrophotometer (ICAP 9000 Jarrel-Ash, Franklin, Mass). Linear and quadratic equations describing tissue K concentrations were determined using PROC REG and a segmented model for quadraticplateau available in the PROC NLIN procedure (SAS Institute, 1985). Potassium carrier data were pooled if no differences in tissue or soil K concentrations due to carrier were found. Least significant difference values were calculated at $P \leq 0.05$ for separation of treatment means.

\section{Results and Discussion}

Clipping yield of both cultivars was increased by highest $\mathrm{K}$ application rate applied to loamy sand. Values for treated vs. control plots were $3.5 \mathrm{vs} .3 .1 \mathrm{~g} \cdot \mathrm{m}^{-2} \cdot \mathrm{d}^{-1}$ for 'Tifdwarf' and 4.0 vs. $3.5 \mathrm{~g} \cdot \mathrm{m}^{-2} \cdot \mathrm{d}^{-1}$ for 'Tifway'. Potassium rates $<195 \mathrm{~kg} \cdot \mathrm{ha}^{-1}$ per month did not influence clipping yield. Potassium application had no effect on growth of grass on sandpeat, perhaps because the higher $\mathrm{N}$ rates applied masked the effect of $\mathrm{K}$.

Average K concentrations in leaf tissues of 'Tifdwarf' and 'Tifway' plants grown in the loamy sand and treated with $\mathrm{K}$ were 3.8 and $2.6 \mathrm{~g} \cdot \mathrm{kg}^{-1}$ higher than those of plants not receiving $\mathrm{K}$, respectively. Parallel increases for plants grown in sand-peat were 4.4 and 5.6 $\mathrm{g} \cdot \mathrm{kg}^{-1}$, respectively. Potassium deficiency was evident on plots not receiving $\mathrm{K}$ (data not shown). Potassium concentrations in leaf tissues were higher in 'Tifdwarf' than in 'Tifway' regardless of $\mathrm{K}$ application rate and soil type (Table 1 and Fig. 1). Liu et al. (1995) reported differences among cultivars of cool-season grasses for absorption kinetics and field recovery of K. Plateau analysis indicated that maximum $\mathrm{K}$ concentrations in 'Tifdwarf' and 'Tifway' leaf tissues were 14.1 and $11.1 \mathrm{~g} \cdot \mathrm{kg}^{-1}$, respectively, when grown in loamy sand, and $16.4 \mathrm{~g}$ and $14.2 \mathrm{~g} \cdot \mathrm{kg}^{-1}$, respectively, when grown in sand-peat (Fig. 1). Data from quadratic plateau models for $\mathrm{K}$ concentration in plant tissues (Fig. 1) were used to determine $\mathrm{K}$ rates that resulted in maximum tissue $\mathrm{K}$ concentration or critical $x$ values. The maximum leaf tissue $\mathrm{K}$ concentrations in 'Tifdwarf' and 'Tifway' grown in loamy sand were achieved at similar $\mathrm{K}$ application rates $\left(\left(78 \mathrm{~kg} \cdot \mathrm{ha}^{-1}\right.\right.$ per month) (Fig. 1). When plants were grown in sand-peat, no increases in $\mathrm{K}$ tissue concentrations occurred in 'Tifdwarf' at $\mathrm{K}$ application rates $>74 \mathrm{~kg} \cdot \mathrm{ha}^{-1}$ or in 'Tifway' at rates $>84$ kg.ha ${ }^{-1}$ (Fig. 1).

Excess soil K reduced both soil and tissue
Table 1. Mean square from combined analyses of variance for tissue $\mathrm{K}, \mathrm{Ca}$, and $\mathrm{Mg}$ concentration in bermudagrass grown in loamy sand and sand-peat and for Mehlich-1 extractable soil $\mathrm{K}, \mathrm{Ca}$, and $\mathrm{Mg}$.

\begin{tabular}{|c|c|c|c|c|c|c|c|}
\hline \multirow[b]{2}{*}{ Source of variation } & \multirow[b]{2}{*}{ df } & \multicolumn{3}{|c|}{ Loamy sand } & \multicolumn{3}{|c|}{ Sand-peat } \\
\hline & & $\mathrm{K}$ & $\mathrm{Ca}$ & $\mathrm{Mg}$ & $\mathrm{K}$ & $\mathrm{Ca}$ & $\mathrm{Mg}$ \\
\hline & & \multicolumn{6}{|c|}{ Tissue concentration } \\
\hline Cultivar, C & 1 & $* * *$ & $* * *$ & $* * *$ & $* * *$ & $* * *$ & $* * *$ \\
\hline $\operatorname{Rep}(\mathrm{C}), \mathrm{R}$ & 6 & $* * *$ & NS & NS & NS & NS & NS \\
\hline K Source, KS & 1 & NS & NS & NS & NS & NS & NS \\
\hline K Rate, KR & 5 & $* * *$ & $* * *$ & $* * *$ & $* * *$ & $* * *$ & $* * *$ \\
\hline $\mathrm{KS} \times \mathrm{KR}$ & 5 & NS & NS & NS & NS & NS & NS \\
\hline $\mathrm{KR} \times \mathrm{C}$ & 5 & $* * *$ & $* * *$ & $* * *$ & $* * *$ & $* * *$ & $* * *$ \\
\hline $\mathrm{KS} \times \mathrm{C}$ & 1 & NS & NS & NS & NS & NS & NS \\
\hline $\mathrm{KR} \times \mathrm{KS} \times \mathrm{C}$ & 5 & NS & NS & NS & NS & NS & NS \\
\hline \multirow[t]{2}{*}{$\mathrm{cv}, \%$} & & 13 & 23 & 15 & 15 & 22 & 18 \\
\hline & & \multicolumn{6}{|c|}{ Soil concentration } \\
\hline Cultivar, C & 1 & $* * *$ & $* * *$ & NS & $* *$ & $* * *$ & $* * *$ \\
\hline $\operatorname{Rep}(\mathrm{C}), \mathrm{R}$ & 6 & $* * *$ & NS & NS & NS & NS & NS \\
\hline K Source, KS & 1 & NS & $* *$ & NS & NS & NS & NS \\
\hline K Rate, KR & 5 & $* * *$ & $* * *$ & $* * *$ & $* * *$ & $* * *$ & $* * *$ \\
\hline $\mathrm{KS} \times \mathrm{KR}$ & 5 & NS & $* *$ & $* *$ & $* * *$ & NS & NS \\
\hline $\mathrm{KR} \times \mathrm{C}$ & 5 & $* * *$ & $* *$ & NS & $* *$ & NS & $* *$ \\
\hline $\mathrm{KS} \times \mathrm{C}$ & 1 & NS & $*$ & NS & NS & NS & NS \\
\hline $\mathrm{KR} \times \mathrm{KS} \times \mathrm{C}$ & 5 & NS & ** & $* *$ & $* * *$ & NS & NS \\
\hline $\mathrm{Cv}, \%$ & & 39 & 28 & 22 & 39 & 22 & 23 \\
\hline
\end{tabular}

Ns, $, * * *, * * *$ Nonsignificant or significant at $P \leq 0.05,0.01$, or 0.001 , respectively.

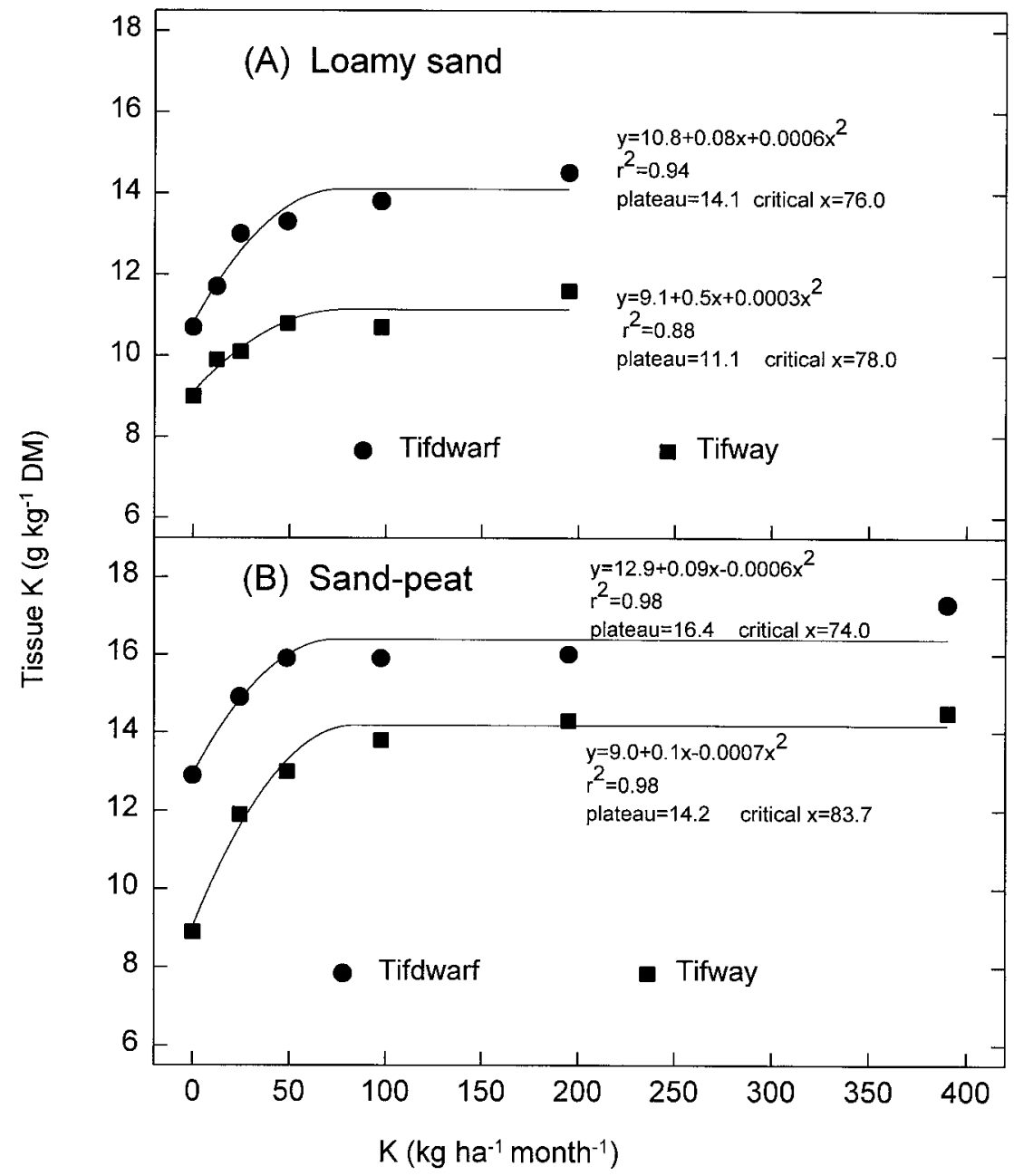

Fig. 1. Effects of $\mathrm{K}$ application on K concentrations of 'Tifdwarf' and 'Tifway' bermudagrass leaf tissues grown on (A) loamy sand and (B) sand-peat. Individual values are expressed as means of $\mathrm{K}$ carriers $\mathrm{KCl}$ and $\mathrm{K}_{2} \mathrm{SO}_{4}$ and 12 sampling dates as a function of $\mathrm{K}$ application rate. Plateau values are the maximum predicted $\mathrm{K}$ tissue concentrations. Critical $\mathrm{x}$ values are predicted $\mathrm{K}$ application rates at maximum $\mathrm{K}$ tissue concentrations. 
$\mathrm{Ca}$ and $\mathrm{Mg}$ concentrations (Fig. 2). Tissue concentrations of both $\mathrm{Ca}$ and $\mathrm{Mg}$ were much higher in 'Tifdwarf' than in 'Tifway' (Table 1 and Fig. 2). The total quantity accumulated in the tissue may have been similar, but the slower growth rate of 'Tifdwarf' may have contributed to the lower concentrations. The decline in $\mathrm{Ca}$ and $\mathrm{Mg}$ concentrations with increasing $\mathrm{K}$ rates were also much more apparent in 'Tifdwarf' than in 'Tifway'. Both reduced soil concentrations of $\mathrm{Ca}$ and $\mathrm{Mg}$ and competitions with $\mathrm{K}$ for plant uptake may have reduced tissue concentrations. Other researchers have also reported that $\mathrm{Ca}$ and $\mathrm{Mg}$ concentrations in plants may decrease with increased Kapplications because of competition (Cripps et al., 1989; Reneau et al., 1983; Sartain, 1993). Barber (1968) indicated that $\mathrm{K}$ is absorbed and accumulated by plants much more rapidly and to a much greater degree than are $\mathrm{Ca}$ and $\mathrm{Mg}$. An increase in clipping yield following application of $195 \mathrm{~kg} \cdot \mathrm{ha}^{-1}$ per month of $\mathrm{K}$ to loamy sand also may have contributed to the reduction in tissue $\mathrm{Ca}$ and $\mathrm{Mg}$ concentrations because of dilution. Sartain (1993) reported that adding $200 \mathrm{~kg} \cdot \mathrm{ha}^{-1} \mathrm{~K}$ to a fine sand increased 'Tifway' clipping yield while depleting soil extractable Ca reserves. Excess application of $\mathrm{K}$ resulted in tissue concentrations well below the sufficiency ranges for $\mathrm{Ca}$ and Mg suggested by Jones et al. (1991).

Levels of extractable $\mathrm{K}, \mathrm{Ca}$, and $\mathrm{Mg}$ in both media were significantly affected by K fertilization (Table 1). The relationship between extractable $\mathrm{K}$ in the soil and $\mathrm{K}$ application was positive and linear (Fig. 3). Data from quadratic plateau models for $\mathrm{K}$ concentration in plant tissues were used to evaluate extractable $\mathrm{Ca}$ and $\mathrm{Mg}$ lost in the root zones when $\mathrm{K}$ rates were applied beyond maximum $\mathrm{K}$ concentration in the tissue (critical x values, Fig. 1). Soil extractable concentrations measured at the highest $\mathrm{K}$ application rate were lower than the concentration measured at the critical $\mathrm{x}$ values (Fig. 4). Extractable $\mathrm{Ca}$ in 'Tifdwarf' in the loamy sand was reduced $8 \%$ by addition of $\mathrm{K}$ at $195 \mathrm{~kg} \cdot \mathrm{ha}^{-1}$ per month compared with the additions of $76.0 \mathrm{~kg} \cdot \mathrm{ha}^{-1}$ per month; in 'Tifway' the reduction was $13 \%$ in comparison with the $78.0 \mathrm{~kg} \cdot \mathrm{ha}^{-1}$ per month rate (Fig. 4). Extractable $\mathrm{Mg}$ in loamy sand was reduced $10 \%$ when $\mathrm{K}$ was applied at $390 \mathrm{~kg} \cdot \mathrm{ha}^{-1}$ per month, regardless of cultivar. In 'Tifdwarf' in the sandpeat, extractable Ca was reduced $22 \%$ and $\mathrm{Mg}$ $29 \%$ (Fig. 4.). The reductions in 'Tifway' were $22 \%$ and $18 \%$, respectively. Sand-peat had a lower innate capacity to retain nutrients than did loamy sand. The highest $\mathrm{K}$ rates were 2.5 to 4.5 greater than those required to obtain the maximum tissue concentration of $\mathrm{K}$.

These results indicate that a linear increase in extractable $\mathrm{K}$ concentrations in loamy sand and sand-peat does not result in a linear increase in tissue $\mathrm{K}$ concentration. There was a critical K fertilization level (74 to $84 \mathrm{~kg} \cdot \mathrm{ha}^{-1}$ per month, depending on grass and soil type) beyond which the tissue concentration remained stable. Fertilizing bermudagrass at higher rates decreased extractable $\mathrm{Ca}$ and $\mathrm{Mg}$ regardless of medium, and tissue $\mathrm{Ca}$ and $\mathrm{Mg}$ concentrations paralleled extractable concen-

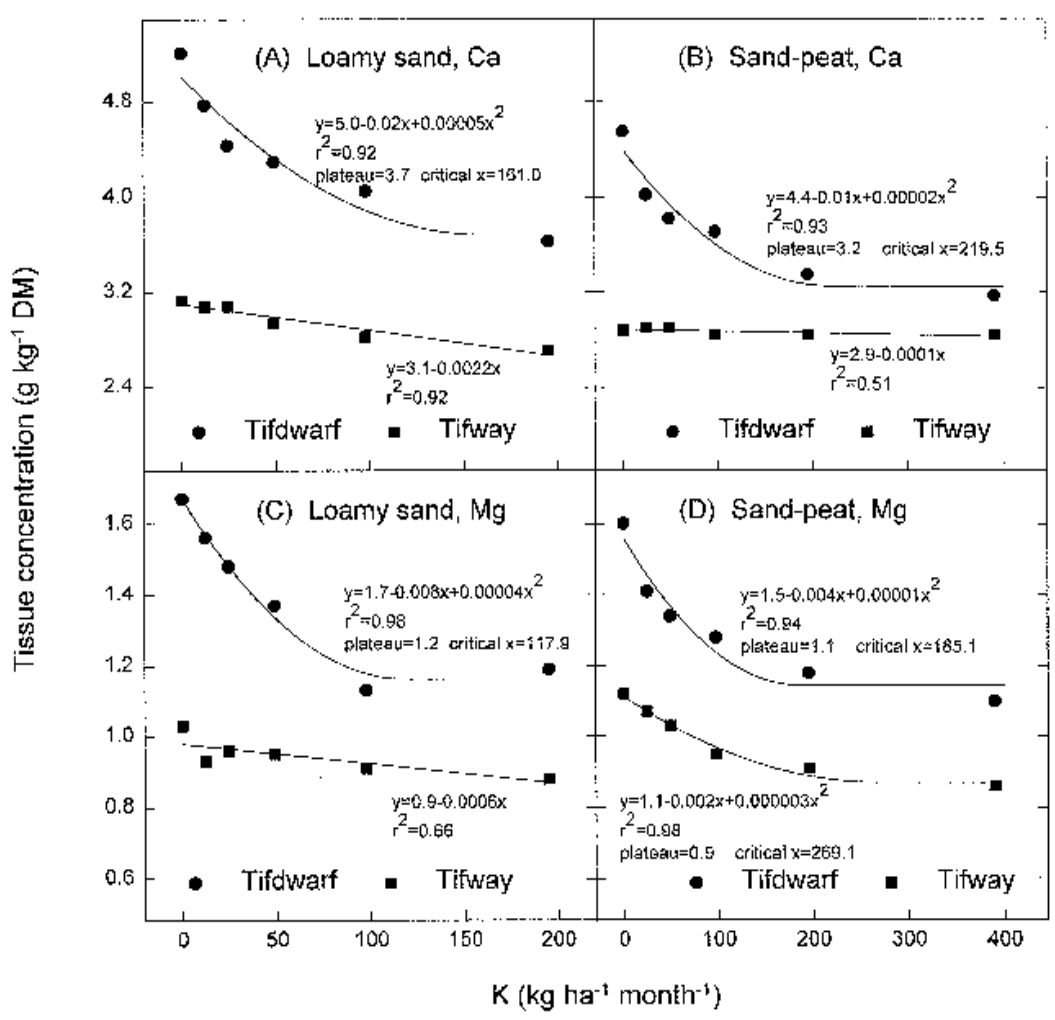

Fig. 2. Effects of $K$ application on (A, B) calcium and (C, D) magnesium concentrations of 'Tifdwarf' and 'Tifway' bermudagrass leaf tissue grown on $(\mathbf{A}, \mathbf{C})$ loamy sand and $(\mathbf{B}, \mathbf{D})$ sand-peat. Individual values are expressed as means of 12 sampling dates as a function of $\mathrm{K}$ application rates. Plateau values are the minimum predicted $\mathrm{Ca}$ and $\mathrm{Mg}$ concentrations. Critical $\mathrm{x}$ values are predicted $\mathrm{K}$ application rates at minimum $\mathrm{Ca}$ and $\mathrm{Mg}$ tissue concentrations.

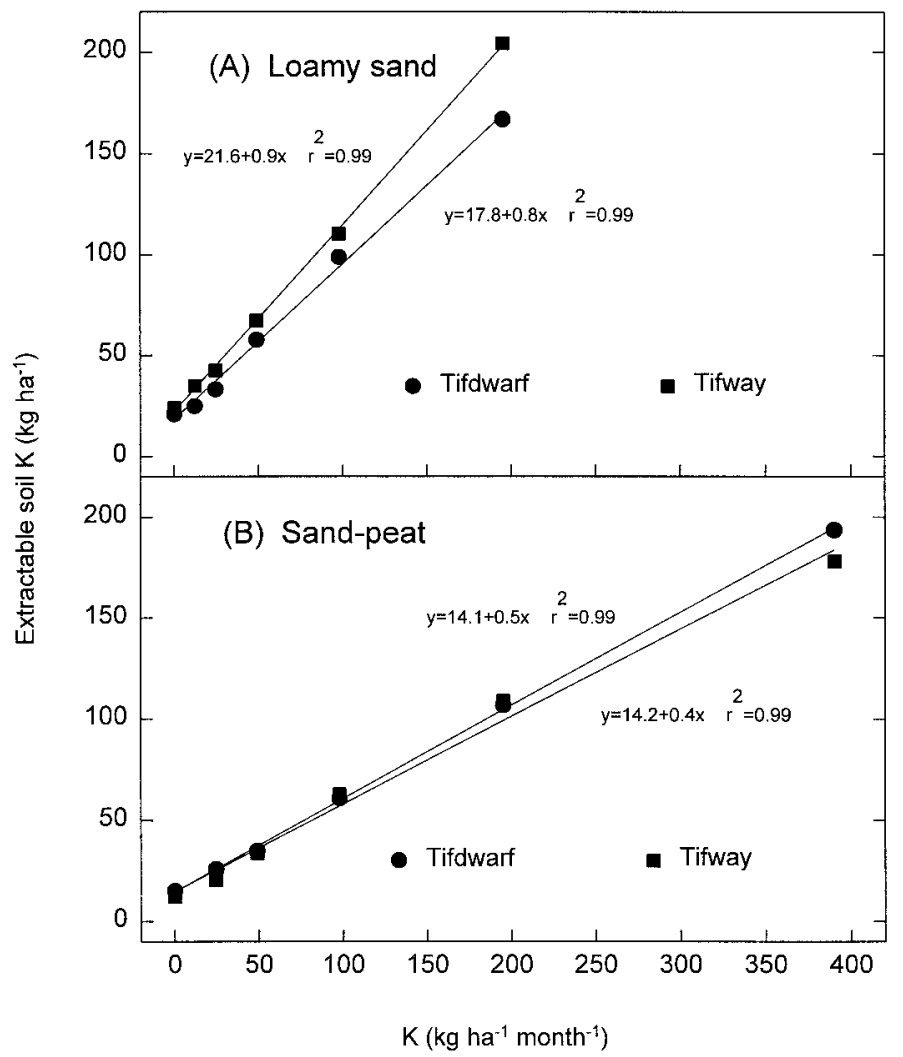

Fig. 3. Effects of K application on Mehlich-1 extractable soil potassium (K) concentrations in (A) loamy sand and (B) sand-peat. Individual values are expressed as means of 13 sampling dates and $\mathrm{K}$ carriers $\mathrm{KCl}$ and $\mathrm{K}_{2} \mathrm{SO}_{4}$ as a function of $\mathrm{K}$ application rates. 


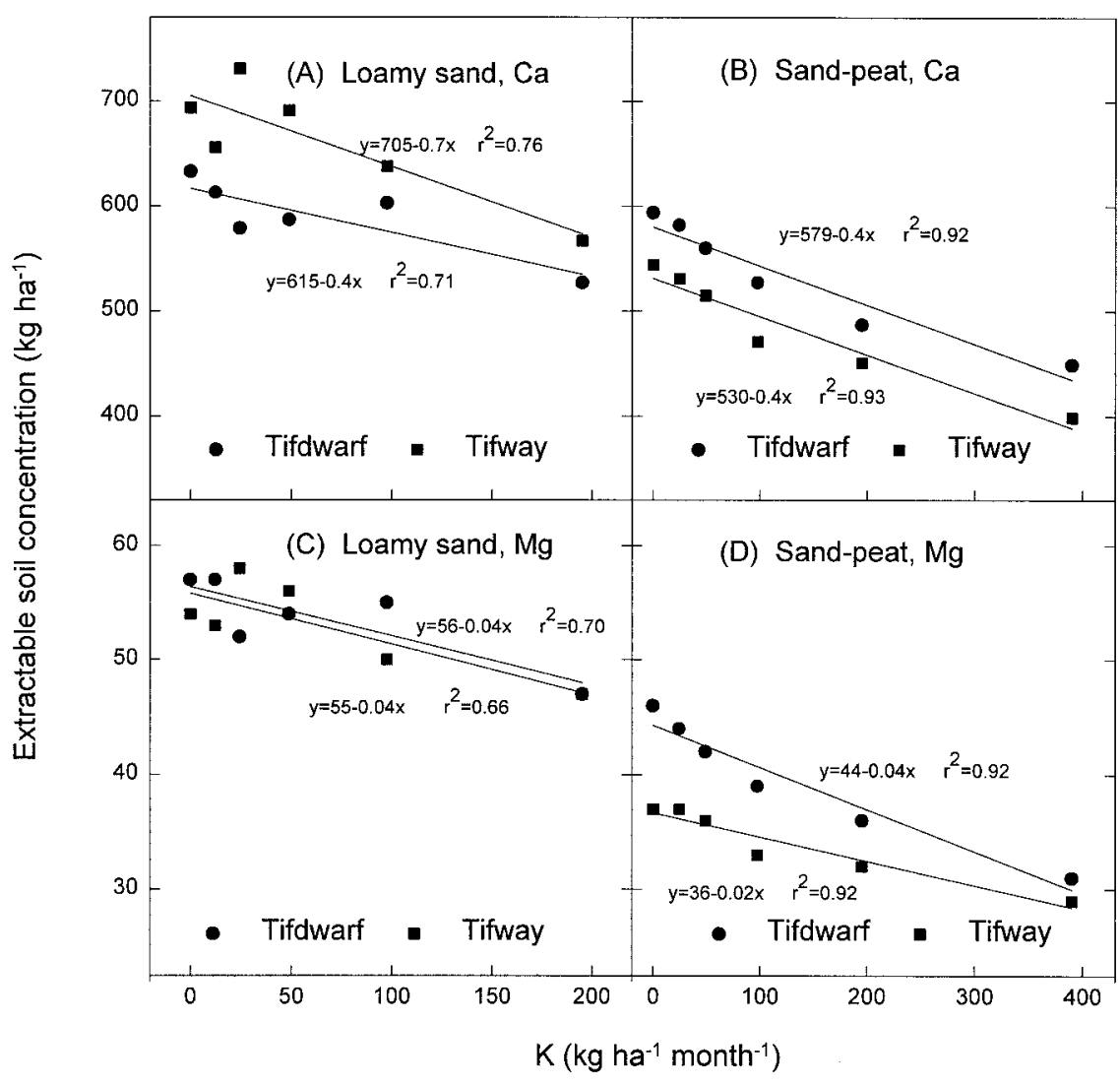

Fig. 4. Effects of $\mathrm{K}$ application on Mehlich-1 extractable (A, B) calcium and (C, D) magnesium concentrations in $(\mathbf{A}, \mathbf{C})$ loamy sand and $(\mathbf{B}, \mathbf{D})$ sand-peat. Individual values are expressed as means of 13 sampling dates as a function of $\mathrm{K}$ application rates.

trations in the root zones. Monitoring is especially important for high-maintenance turf, since many current recommendations suggest application of high rates of $\mathrm{K}$ fertilizers to enhance turfgrass stress tolerance. Frequent tissue analysis can aid in determining sufficiency levels for $\mathrm{K}$, thereby avoiding reduced tissue $\mathrm{Ca}$ and $\mathrm{Mg}$ levels resulting from excess applications of $\mathrm{K}$ to the soil.

\section{Literature Cited}

Adams, W.E., A.W. White, R.A. McCreery, and R.N. Dawson. 1967. Coastal bermudagrass forage production and chemical composition as influenced by potassium source, rate, and frequency of application. Agron. J. 59:247-250.

Barber, S.A. 1968. Mechanisms of potassium absorption by plants, p. 293-303. In: V.J. Kilmer, S.E. Younts, and N.C. Brady (eds.). The role of potassium in agriculture. ASSA, CSSA, and SSA, Madison, Wis.
Beard, J.B. 1973. Turfgrass: Science and culture. Prentice-Hall, Englewood Cliffs, N.J.

Belesky, D.P. and S.R. Wilkinson. 1983. Response of 'Tifton 44' and 'Coastal' bermudagrass to soil $\mathrm{pH}, \mathrm{K}$, and $\mathrm{N}$ source. Agron. J. 75:1-5.

Cripps, R.W., J.L. Young, and A.T. Leonard. 1989. Effects of potassium and lime applied for coastal bermudagrass production on sandy soil. Soil Sci. Soc. Amer. J. 53:127-132.

Hannaway, D.B., L.P. Bush, and J.E. Leggett. 1980. Plant nutrition: Magnesium and hypomagnesemia in animals. Kentucky Agr. Expt. Sta. Bul. 716.

Horn, G.C. 1969. Potassium fertilizers for 'Tifway' bermudagrass, p. 205-211. In: J.B. Beard (ed.). Proc. 1st Intl. Turfgrass Res. Conf., 15-18 July. Harrogate, England

Hue, N.V. and C.E. Evans. 1986. Procedures used for soil and plant analysis by the Auburn Univ. Soil Testing Laboratory. Dept. Agron. and Soils. Dept. Series 106. Auburn Univ., Ala.

Jones, J.B., Jr., B. Wolf, and H.A. Mills. 1991. Plant analysis handbook. MicroMacro Publ., Athens, $\mathrm{Ga}$.

Landua, D.P., A.R. Swoboda, and G.W. Thomas. 1973. Response of coastal bermudagrass to soil applied sulfur, magnesium, and potassium. Agron. J. 51:541-544.

Liu, H., R.I. Hull, and D.T. Duff. 1995. Comparing cultivars of three cool-season turfgrasses for potassium uptake kinetics and potassium recovery in the field. J. Plant Nutr. 18:467-485.

Kamon, Y. 1974. Magnesium deficiency in zoysiagrass, p. 145-148. In: E.C. Roberts (ed.). Proc 2nd Intl. Turfgrass Res. Conf., Blacksburg, Va., 19-21 June 1973. ASA and CSSA, Madison, Wis.

Martin, W.E. and J.E. Matocha. 1973. Plant analysis as an aid in the fertilization of forage crops, $\mathrm{p}$. 393-426. In: L.M. Walsh and J.D. Beaton (eds.). Soil testing and plant analysis. SSSS, Madison, Wis.

Matocha, J.E. and L. Smith 1980. Influence of potassium on Helminthosporium cynodontis and dry matter yields of 'Coastal' bermudagrass. Agron. J. 72:565-567.

McIntosh, M.S. 1983. Analysis of combined experiments. Agron. J. 75:153-155.

Miller, G.L. and R. Dickens. 1995. Leaf water potential and drought stress recovery as affected by potassium fertilization. Agronomy abstr. (Appen. 1, p. 10). ASA, Madison, Wis.

Moore, L.D., H.B. Couch, and J.R. Bloom. 1961 Influence of nutrition, $\mathrm{pH}$, soil temperature, and soil moisture on pythium blight of Highland bentgrass. Phytopathology 51:578.

Razmjoo, K. and S. Kaneko. 1993. Effect of potassium rate on growth, quality, chemical composition, and winter hardiness of perennial ryegrass. J. Plant Nutr. 16:195-201.

Reneau, R.B., Jr., G.D. Jones, and J.B. Friedericks. 1983. Effect of $\mathrm{P}$ and $\mathrm{K}$ on yield and chemical composition of forage sorghum. Agron. J. 75:5-

Robinson, D.L. 1985. Potassium nutrition of forage grasses, p. 895-914. In: R.D. Munson (ed.). Potassium in agriculture. ASA, CSSA, and SSA, Madison, Wis.

Sartain, J.B. 1993. Interrelationships among turfgrasses, clipping recycling, thatch, and applied calcium, magnesium, and potassium. Agron. J. 85:40-43.

SAS Institute. 1985. The NLIN procedure, p. 575614. In: SAS user's guide: Statistics. 5th ed. SAS Inst., Cary, N.C.

Schmidt, R.E. and J.M Breuninger. 1981. The effects of fertilization on recovery of Kentucky bluegrass turf from summer drought, p. 333339. In: R.W. Sheard (ed.). Proc. 4th Intl. Turfgrass Res. Conf., Huddleston \& Barney, Woodstock, Ont.

West, J.W. and J.H. Reynolds. 1984. Cation composition of tall fescue forage as affected by $\mathrm{K}$ and Mg fertilization. Agron. J. 76:676-680. 